\title{
KOMUNIKASI BISNIS BERORIENTASI PELANGGAN DI PERUSAHAAN DISTRIBUSI
}

\author{
Dwi Nurul Prihantono \\ Prodi Ilmu Komunikasi Stisipol Candradimuka Palembang \\ dn.prihantono@yahoo.co.id
}

\begin{abstract}
Abstrak
Salah satu keberhasilan bisnis perusahaan distribusi sangat ditentukan bagaimana membangun komunikasi dengan pelanggan. Pelanggan merupakan partner bisnis yang sangat penting bagi perusahaan karena disinilah proses interaksi produk, proses, dan jasa perusahaan yang sekaligus sebagai bagian dari rantai proses perusahaan dalam menyediakan produk dan jasa baik sebagai pengguna perantara maupun pengguna akhir. Penelitian ini untuk menggambarkan bagaimana perusahaan distribusi membangun konsep komunikasi yang tepat dan efektif dalam mengidentifikasi, menjaga kebutuhan serta keinginan pelanggan. Perusahaan harus mampu menerapkan komunikasi yang optimal dalam meningkatkan kinerja perusahaan dan mempertahankan keberlangsungan bisnis jangka panjang terutama yang berkaitan dengan pelanggan. Penelitian ini menggunakan paradigma kualitatif dengan metode deskriptif analisis. Data diperoleh melalui wawancara langsung dan tidak langsung, Focus Group Discussion, tinjauan literature serta dokumentasi.
\end{abstract}

Kata Kunci : Perusahaan Distribusi, Komunikasi, Pelanggan

\begin{abstract}
One of the business success of the distribution company is determined from how the company builds communication with the customers. Customer is an important business partner of the company because this is where the process of interaction of products, processes, and services of the company as a part of the company's chain process in providing products and services, both as an intermediary user and last user. This research is conducted to illustrate how the distribution company builds appropriate and effective communication concepts in identifying and maintaining customer's needs and desires. Companies must be able to implement optimal communication in order to improve company performance and to maintain a long-term business continuity, especially those which are related to the customers. This research used qualitative paradigm with descriptive method of analysis. Data were obtained through direct and indirect interviews, focus group discussions, literature review and documentation.
\end{abstract}

Keywords : Distribution company, communication, customer 


\section{Pendahuluan}

Komunikasi dalam kaitan dengan pelanggan merupakan aspek yang sangat penting bagi keberlangsungan bisnis perusahaan., karena perusahaan akan berhubungan banyak dengan pihak-pihak yang berkepentingan terhadap aktivitas bisnis perusahaan terutama ketika berhubungan dengan stakeholders. Dengan adanya komunikasi antara perusahaan dengan pelanggan memungkinkan terjadinya koordinasi timbal balik, perintah, instruksi, saran dan pendapat serta pertukaran informasi secara cepat, tepat dan jelas sehingga tujuan perusahaan serta keinginan pelanggan dapat disinergikan dalam kerangka hubungan kerja sama yang saling menguntungkan.

Perusahaan distribusi mempunyai perananyang sangat penting dalam proses penyediaan barang, fungsi distribusi adalah sebagai pengubung agar produk yang telah diproduksi dapat sampai ke konsumen sesuai dengan kebutuhan konsumen tersebut. Dalam pengertiannya Perusahaan distribusi merupakan suatu badan organisasi yang dapat menyediakan barang dan memiliki rekanan rekanan untuk menjual barangnya kembali dengan harga yang tinggi untuk mendapatkan keuntungan sebesar-besarnya (Keegan, 2007;134).

Bagi perusahaan distribusi pelanggan merupakan mitra atau partner strategis bagi berkembangnya sebuah perusahaan. Pelanggan berfungsi sebagai pemberi masukkan yang penting bagi perusahaan sehingga dapat memperbaiki kinerjanya sehingga dapat memberikan nilai tambah dan value bagi perusahaan terutama dalam peningkatan penjualan yang dapat memberikan laba lebih bagi perusahaan. Menurut Blattberg, Getz, dan Thomass (2001) disampaikan pelanggan merupakan aset keuangan bagi sebuah perusahaan yang harus diukur, dijaga, dan dimaksimalkan seperti aset-aset lainnya.

Menurut Kotler dan Amstrong (2009) dikatakan bahwa pelanggan merupakan orang yang paling diharapkan kedatangannya bagi perusahaan. untuk itu dapat dikatakan betapa berharganya pelanggan bagi perusahaan karena pelanggan merupakan orang yang berinteraksi dengan produk, proses, dan jasa perusahaan yang sekaligus sebagai bagian dari rantai proses perusahaan dalam menyediakan produk dan jasa baik sebagai pengguna perantara maupun pengguna akhir. Harapan besar dari perusahaan kepada pelanggan adalah tumbuhnya pelanggan-pelanggan loyal dan setia yang menunjukkan perilaku pembelian secara teratur yang menjadi aset besar bagi laba dan pertumbuhan perusahaan.

\section{Tujuan Penelitian}

Melihat permasalahan yang sudah dikemukakan di atas, tujuan penelitian ini adalah bagaimana perusahaan distribusi membangun konsep komunikasi yang tepat dan efektif dalam mengidentifikasi, menjaga kebutuhan serta keinginan pelanggan. 


\section{Kerangka Teori}

\subsection{Pelanggan}

Lupiyoadi (2001:134) mendefinisikan Pelanggan adalah seorang individu yang secara continue dan berulang kali datang ke tempat yang sama untuk memuaskan keinginannya dengan memiliki suatu produk atau mendapatkan suatu jasa dan memuaskan produk atau jasa tersebut. Menurut Gasperz dalam (Nasution, 2005:101) pelanggan adalah semua orang yang menuntut perusahaan untuk memenuhi suatu standar kualitas tertentu yang akan memberikan pengaruh pada performansi perusahaan dan manajemen perusahaan. Dari semua pendapat para ahli diatas dapat disimpukan bahwa pelanggan adalah individu yang melakukan pembelian kebutuhan yang bisa membuat puas dengan membandingkan beberapa aspek seperti harga, standar kualitas barang atau jasa dalam rangka memenuhi kebutuhan pribadi dan rumah tangga.

Pelanggan menurut Cambridge International Dictionaries dalam Lupiyoadi (2001:143), adalah "a person who buys goods or a services" atau pelanggan adalah seseorang yang membeli barang dan jasa. Sementara menurut Webster's 1928 Dictionary dalam Lupiyoadi (2001:143) pelanggan adalah "one who frequents any place of sale for producing what he wants ...". (Pelanggan adalah seseorang yang beberapa kali datang ke tempat yang sama untuk memenuhi apa yang diinginkan..).

What is a customer? Menurut Nasution (2005:45); dan Gaspersz (1997:73) pelanggan adalah semua orang yang menuntut organisasi untuk memenuhi standar kualitas tertentu, dan karena itu memberikan pengaruh pada kinerja organisasi. Oleh karena itu menurut Bean dan Maine (dalam Nasution, 2005:46) pelanggan adalah:

(1) orang yang tidak tergantung pada perusahaan, tetapi sebaliknya;

(2) orang yang membawa organisasi untuk mengikuti keinginannya;

(3) orang yang teramat penting yang harus dipuaskan.

Dalam kegiatan bisnis pelanggan dibedakan dalam 3 ( Tiga) kategori jenis pelanggan, yaitu:

1. Pelanggan Internal

Pelanggan internal merupakan pelanggan yang tidak mengonsumsi suatu barang ataupun jasa secara langsung. Pelanggan tipe ini membeli barang ataupun jasa untuk dijual kembali oleh orang lain. Pelanggan jenis ini dapat berupa produsen suatu barang ataupun agen penjualan yang bekerja sama dengan perusahaan penyedia barang ataupun jasa. Pelanggan jenis ini akan didapatkan oleh perusahaan dengan jalan memberikan berbagai keuntungan untuknya. Dengan memberikan keuntungan yang lebih untuk pelanggan ini, maka pelanggan ini akan tetap setia menjadi pelanggan perusahaan Kita. 
2. Pelanggan Eksternal

Pelanggan eksternal merupakan pelanggan yang secara aktif langsung mengonsumsi barang ataupun jasa yang mereka beli. Pelanggan jenis ini sering juga disebut sebagai konsumen akhir. Pelanggan tipe ini biasanya berhasil didapatkan oleh sebuah perusahaan dikarenakan mutu dan kualitas dari barang ataupun jasa yang dirasakan oleh pelanggan ini. Dengan memberikan kualitas terbaik dari barang ataupun jasa yang kita jual, kita akan mendapatkan komitmen yang besar dari pelanggan eksternal ini.

3. Pelanggan Antara

Merupakan kelompok atau orang yang bertindak sebagai perantara produk, akan tetapi bukan sebagai pemakai akhir dari produk perusahaan. Misalnya seperti agen perjalanan yang bertindak sebagai pemesan kamar penginapan untuk para pemakai akhir (konsumen) atau seperti distributor yang bertindak dalam mendistristibusikan produk-produk milik perusahaan kepada para pengecer.

Aktivitas hubungan bisnis perusahaan harus selalu dekat dengan pelanggan, sehingga diharapkan terjaga dan terciptanya hubungan yang harmonis dan berkelanjutan. Untuk itu perlu dibangun hubungan pondasi yang kuat dengan pelanggan. Adapun karakteristik hubungan yang harus dibangu antara perusahaan dan pelanggan diantaranya adalah sebagai berikut :

a. Interaksi

Hubungan yang terjalin antara perusahaan dengan pelanggan terbentuk karena adanya interaksi diantara keduanya, dimana interaksi tersebut akan menghasilkan pertukaran informasi. Informasi yang telah dihasilkan dikelola dan menjadi sumber data dalam membangun dan membina hubungan.

b. Saling Menguntungkan

Hubungan yang terjadi antara perusahaan dan pelanggan adalah menghasilkan keuntungan bagi keduanya. Perusahaan akan memperoleh kepercayaan serta loyalitas dari pelanggan sebaliknya pelanggan akan mendapatkan kepuasan terhadap layanan perusahaan.

c. Tumbuh dan Berkembang

Hubungan antara perusahaan dan pelanggan tumbuh dan berkembang karena adanya interaksi yang saling menguntungkan antara perusahaan dan pelanggan yang berkelanjutan.

d. Manfaat Jangka Panjang

Hubungan antara perusahaan dan pelanggan akan memberikan manfaat baik disaat ini yang sedang berjalan ataupun dimasa yang akan mendatang, terlebih jika hubungan tersebut dilandasi rasa sama- sama susah dan sama- sama senang sehingga ketika terjadi permasalahan dapat dicarikan jalan pemecahan bersama-sama. 
e. Hubungan bersifat personal

Hubungan antara perusahaan dengan pelanggan bersifat personal. Perusahaan harus mampu memahami tipe-tipe pelanggannya. Oleh karena itu perusahaan harus mampu menerapkan pola interaksi dan komunikasi yang berbeda-beda kepada pelanggannya.

f. Kepercayaan

Hubungan yang baik membutuhkan kepercayaan. Jika pelanggan cenderung menjalin hubungan yang intens dengan perusahaan, maka pelanggan telah memberikan kepercayaan yang baik kepada perusahaan.,

Dalam aktivitas bisnis terutama di perusahaan distributor, perusahaan harus mampu mengetahui, memahami apa itu pelanggan dan bagaimana cara mengelola pelanggan agar tetap menjadi bagian penting bagi perusahaan, untuk itu lebih spesifik lagi, sifat-sifat pelanggan dapat digambarkan sebagai berikut :

a. Pelanggan Pengambil Keputusan ( The Decided Customer)

Pelanggan dengan sifat ini telah mengetahui apa yang diinginkan oleh perusahaan dan memahami aturan yang telah diterapkan oleh perusahaan, sehingga ketika melayani pelanggan tersebut harus cepat. Untuk menghadapi pelanggan dengan sifat ini apabila ada pertanyaan-pertanyaan, dalam memberikan jawaban atau keterangan kepadanya harus bersifat khusus, tidak perlu memberikan keterangan yang bersifat umum.

b. Pelanggan yang Seolah Serba Tahu (The Know It All Customer)

Sifat pelanggan yang seolah-olah mengetahui segalanya mengenai produk dan layanannya, pelanggan yang bercerita kepada perusahaan walaupun apa yang diungkapkannya tidak seluruhnya benar, tetapi perusahaan tidak perlu membantahnya. Untuk menghadapi pelanggan dengan sifat ini, perusahaan dapat memberikan penjelasan -penjelasan yang tepat secara bijaksana dengan cara menempuh cara yang tidak langsung dan ini dapat mempengaruhi sifat pelanggan tersebut.

c. Pelanggan yang Menghendaki Fakta ( The Deliberate Customer) Sifat pelanggan yang menghendaki fakta-fakta sehingga perusahaan perlu melakukan edukasi mengenai penggunaan produk yang akan dibelinya. Sifat pelanggan seperti ini membutuhkan waktu yang lama dalam mengambil keputusan untuk melakukan pembelian.

d. Pelanggan Sukar Mengambil Keputusan ( The Undecided Customer) Sifat pelanggan yang sukar dalam mengambil keputusan biasanya mereka kesulitan mengenai type, jenis, ukuran produk yang akan dibelinya. Untuk menghadapi pelanggan dengan sifat seperti ini adalah dengan mencoba menentukan apa yang sebenarnya dibutuhkan oleh pelanggan tersebut. Perusahaan harus berusaha dan mampu membantu pelanggan dalam mengambil keputusan. 
e. Pelanggan yang Aktif Berbicara ( The Talkative Customer)

Ini merupakan sifat pelanggan yang biasanya tidak mempunyai kepastian, biasanya pelanggan ini sangat senang mengobrol tetapi tidak mempunyai arah pembicaraan kepada pembelian. Untuk menghadapinya perusahaan bisa melayani obrolan atau pembicaraannya sambil sedikit demi sedikit mengarahkan pembicaraan ke pembelian.

f. Pelanggan yang Grogi (The Silent Timid Customer)

Sifat pelanggan yang grogi, biasanya agak canggung dan merasa takut jika kekurangan pengetahuan nya tentang suatu produk akan menjadi nyata ketika yang bersangkutan ditanya-tanya. Untuk menghadapi pelanggan seperti ini adalah dengan cara tidak menunjukkan kesan bahwa pelanggan tidak mengetahui apa-apa tentang suatu produk.

g. Pelanggan Pengambil Keputusan Namun Salah ( The Decided But Mistaken Customer) Sifat pelanggan yang sudah mempunyai rencana yang pasti dalam melakukan pembelian, tetapi menurut perusahaan pilihan pelanggan tidak sesuai dengan mahsud penggunaannya. Untuk mengahdapi pelanggan yang seperti ini tidak perlu berdebat dengannya tetapi cukup menyarankan penggunaan dan manfaat dari barang tersebut dan menyampaikan apa barang yang seharusnya dibeli.

h. Pelanggan yang Menyukai Discount ( The I Get Discount Customer)

Sifat pelanggan yang selalu menghendaki potongan harga atau hadiah atas barang yang dibeli. Untuk menghadapinya cukup dengan menginformasikan produk-produk yang ada discountnya atau periode-periode tertentu produk yang kan dibelinya mengeluarkan program discount.

\subsection{Komunikasi bisnis berorientasi pelanggan}

Terkait pentingnya komunikasi dalam kegiatan bisnis, perusahaaan perlu memahami bagaimana konsep komunikasi yang tepat dan efektif dalam berhubungan dengan pelanggan. Perusahaan harus mampu menerapkan komunikasi yang optimal dalam meningkatkan kinerja perusahaan dan bagaimana mempertahankan keberlangsungan bisnis jangka panjang terutama yang berkaitan dengan pelanggan-pelanggan mereka.

Komunikasi menurut Hovlan, Janis dan Kelley (Muhammad, 2009:2) adalah proses individu mengirim stimulus yang biasanya dalam bentuk verbal untuk mengubah tingkah laku orang lain. Komunikasi adalah suatu proses sosial yang terjadi setidaknya dua orang, dimana ri orang atau pihakindividu mengirim stimulus kepada orang lain. Stimulus disebut sebagai pesan berupa proses penyampaian yang dilakukan melalui saluran komunikasi sehingga terjadi perubahan atau respon atas pesan yang disampaikan.

Menurut Mulyana (2002), komunikasi dapat dipandang dalam berbagai macam perspektif, diantaranya adalah :

1. Komunikasi Sebagai Tindakan Satu Arah

Komunikasi adalah proses penyampaian pesan dari seseorang kepada pihak lain, baik 
langsung melaluin tatap muka ataupun tidak langsung dengan mengggunakan media. Contohnya adalah perusahaan mempunyai pesan berupa program partnership kepada pelanggan, dan pelanggan tersebut menerima dengan baik informasi yang diberikan. Komunikasi yang terjadi berorientasi pada pesan a messagecentered of philosophy of communication. Keberhasilan komunikasi seperti ini terletak pada penguasaan fakta atau informasi dan pengaturan mengenai cara-cara penyampaian fakta atau informasi tersebut.

2. Komunikasi Sebagai Interaksi

Komunikasi di sini diartikan sebagai suatu proses sebab-akibat atau aksi-reaksi secara bergantian baik verbal maupun non-verbal peristiwanya: seseorang (instruktur) menyampaikan suatu informasi kemudian pihak penerima informasi itu memberikan respon atas informasi yang diterimanya itu untuk kemudian pihak pertama bereaksi lagi setelah menerima respon atau umpan balik dari pihak kedua, dan seterusnya.

Komunikasi demikian berorientasi pada pembicara: a speakercentered philosophy of communication dan mengabaikan kemungkinan seseorang bisa mengirim dan atau menerima informasi pada saat yang sama. Disini unsur umpak balik (feed-back) menjadi cukup penting. Bagaimana pihak pengirim dan penerima suatu informasi bisa silih berganti peran karena persoalan umpan balik.

3. Komunikasi Sebagai Transaksi

Komunikasi sebagai transaksi merupakan suatu proses yang bersifat personal karena makna atau arti yang diperoleh pada dasarnya bersifat pribadi. Penafsiran atas suatu informasi melalui proses penyandian (encoding process) dan melalui penyandian kembali (decoding process) dalam peristiwa komunikasi baik atas perilaku verbal ataupun atas perilaku non-verbal bisa amat bervariasi.

Peristiwanya : melibatkan penafsiran yang bervariasi dan pembentukan makna yang lebih kompleks. komunikasi tidak membatasi pada kesengajaan atau respons yang teramati melainkan pula mencakup spontanitas, bersifat simultan dan kontekstual. komunikasi ini berorientasi pada arti baru yang terbentuk : a meaning-centered philosophy of communication.

Kesuksesan bisnis suatu perusahaan sangat berkaitan dengan bagaimana perusahaan membangun hubungan jangka panjang dengan pelanggannya. Untuk itu diperlukan kegiatan komunikasi yang efektif dan efisien sehingga dapat membangun kepuasan pelanggan yang berkelanjutan sehingga akan terbentuk loyalitas pelangggan, dimana pelanggan yang loyal dapat memberikan pertumbuhan bisnis yang besar bagi perusahaan.

Salah satu permasalahan yang sering ditemui oleh beberapa perusahaan saat ini, bagaimana perusahaan tersebut dapat menarik pelanggan yang sebanyak-banyaknya dan juga mempertahankan pelanggan tersebut. Tidak bisa dipungkiri bahwa keberadaan pelanggan 
memang memegang peranan yang sangat penting bagi kemajuan sebuah perusahaan.

Salah satu kegiatan yang dilakukan oleh perusahaan untuk selalu dapat mempertahankan pelanggan sekaligus sebagai bagian dari meningkatnya pertumbuhan pemasaran perusahaan adalah dengan menggunakan kegiatan Relationship marketing. Menurut Keegan, Duncan, dan Moriaty (1995: p.1) Relationship marketing adalah pendekatan pemasaran kepada pelanggannya untuk meningkatkan pertumbuhan jangka panjang perusahaan dan juga untuk mencapai kepuasan maksimum pelanggan.

Dalam relationship, ada beberapa hal yang perlu diperhatikan yaitu:

\section{- Customer Service}

Dalam hal ini, customer Service bisa diartikan sebagai pelayanan tambahan untuk mendukung produk utama. Customer Service ini sangat diperlukan untuk membina hubungan jangka panjang antara produsen (penjual) dengan pelanggan. Customer Service terbagi menjadi dua macam yaitu reactive dan proactive service. Reactive service adalah pelayanan tambahan yang diberikan ketika pelanggan menemukan masalah dengan produk yang kita jual, misalnya dengan melayani klaim garansi, pengembalian barang, dan masih banyak lagi. Sementara proactive service adalah pelayanan tambahan yang diberikan tanpa harus menunggu terjadi sesuatu terhadap produk yang kita jual.

- Community Building

Community Building ini ditujukan untuk membuat komunikasi yang efektif antara penjual dengan pelanggan. Komunikasi ini perlu dilakukan terutama untuk meyakinkan kualitas produk/jasa kita kepada pelanggan. Dewasa ini, komunikasi semacam ini sering dilakukan dengan pembuatan situs web, blog, page, ataupun grup di berbagai jejaring sosial. Bila berbicara mengenai relationship marketing dan kepuasan pelanggan, maka satu hal yang tidak boleh dilupakan adalah kualitas produk yang akan ditawarkan kepada pelanggan. Semakin tinggi kualitas suatu produk, maka akan semakin tinggi pula respons pasar terhadap produk tersebut. Selain itu, beberapa pihak harus bisa saling mempercayai satu dan yang lainnya.

Relationship marketing memang harus dilakukan, terlebih lagi sudah bukan zamannya sebuah perusahaan hanya fokus pada keuntungan hari ini. Sebuah perusahaan sejatinya harus bisa berpikir tentang pengembangan atau masa depan perusahaan. Selain untuk membangun hubungan jangka panjang, relationship marketing juga memiliki beberapa manfaat lainnya, seperti:

- Ikatan struktural

Salah satu manfaat dari relationship marketing adalah untuk menambah ikatan struktural. Maksudnya adalah dengan adanya relationship marketing ini, bisa dipastikan bahwa beberapa badan usaha yang terdapat dalam sebuah perusahaan akan bersatu dan bekerjasama untuk memberikan pendekatan 
atau program yang dapat menarik minat pelanggan. Sebagai contohnya, tim disebuah bank bertugas mencari nasabah atau pengguna kartu kredit.

- Manfaat ekonomis

Relationship marketing sangat menguntungkan untuk penjual dan pembali. Penjual bisa meminimalisasi biaya pemasaran, sedangkan pelanggan tidak akan salah membeli barang (karena rekomendasi teman). Bisa juga dikatakan bahwa relationship marketing ini memiliki manfaat ekonomis karena dapat menghemat biaya yang dikeluarkan oleh pelanggan.

- Manfaat sosial

Dengan adanya relationship marketing, mau tidak mau seorang penjual harus bisa menciptakan hubungan sosial yang baik dengan pelanggan. Salah satu caranya adalah dengan memberikan perhatian kepada para pelanggan secara individual.

Hal tersebut merupakan tantangan karena dengan demikian seorang penjual dituntut untuk mengerti, memahami, dan menempatkan dirinya diposisi pelanggan. Sebagai contoh, seorang penjual harus membayangkan terlebih dahulu bagaimana rasanya jika barang yang ia beli ternyata tidak dapat memuaskannya, dan lain sebagainya.

Keberhasilan perusahaan berkaitan langsung dengan kemampuan perusahaan dalam berkomunikasi dan menjaga hubungan jangka panjang dengan pelanggan. Semakin baik perusahaan dalam berkomunikasi dengan pelanggan maka akan semakin baik pula hubungan yang terjalin dengan pelanggan. Untuk menjaga keberhasilan perusahaan diperlukan tehniktehnik berkomunikasi yang tepat kepada pelanggan, terutama proses komunikasi didalam proses pertukaran pesan sampai terjadinya suatu pembelian. Adapun teknik-teknik komunikasi yang dilakukan kepada pelanggan, yaitu :

1. Negosiasi

Pengertian negosiasi secara sederhana adalah sebuah proses untuk mendapatkan kesepakatan dengan cara memperkecil perbedaan serta mengembangkan kesepakatan sehingga mendapatkan hasil dan tujuan bersama yang saling menguntungkan. Negosiasi dapat dipahami juga sebagai suatu proses ketika kedua belah pihak mencapai perjanjian yang dapat memenuhi kepuasan semua pihak yang berkepentingan dengan elemen-elemen kerjasama. Tindakan yang dilakukan dapat berupa komunikasi, kerja sama atau mempengaruhi orang lain dengan tujuan tertentu. Menurut Wikipedia (2013) negosiasi adalah sebuah bentuk interaksi sosial saat pihak-pihak yang terlibat berusaha untuk saling menyelesaikan tujuan yang berbeda dan bertentangan.

Berdasarkan pendapat diatas, dalam kaitan dengan pelanggan maka negosiasi 
dengan pelanggan merupakan proses yang dinamis antara perusahaan dan pelanggan dalam rangka memperkecil aspek perbedaan dengan mengembangkan aspek persamaan, sehingga kepentingan perusahaan terpenuhi dan kepuasan pelanggan dapat tercipta.

Proses negosiasi tercipta karena timbulnya suatu konflik atau pertentangan. Rue dan Byar (Dalam Somad dan Priansa, 2014:162) menyampaikan bahwa konflik adalah suatu kondisi perilaku yang tidak tersembunyi atau tidak disembunyikan dimana satu pihak ingin memenangkan kepentingannya sendiri diatas kepentingan pihak lain. Pendapat yang lain menurut Degenova (Dalam Somad dan Priansa, 2014:162) disampaikan bahwa konflik adalah sesuatu yang normal terjadi dalam setiap hubungan, dimana dua orang tidak pernah selalu setuju pada suatu keputusan yang dibuat.Kesimpulannya adalah konflik merupakan suatu kondisi dimana satu pihak ingin lebih unggul atau mendominasi pihak yang lainnya, sehingga menimbulkan potensi terjadinya perselisihan antara pihak satu dengan lainnya. Bagi perusahaan konflik dengan pelanggan harus dihindari karena pelanggan merupakan aset yang sangat berharga bagi perusahaan.

Dalam melakukan negosiasi diperlukan strategi komunikasi antara perusahaan dengan pelanggan dengan menggunakan pendekatan-pendekatan agar ditemukan titik temu. Ada beberapa model pendekatan yang biasanya dilakukan dalam proses negosiasi. Pendekatan tersebut dapat dilihat dalam tabel dibawah ini.

Tabel 1

Pendekatan Negosiasi

\begin{tabular}{|c|c|}
\hline Pendekatan & Penjelasan \\
\hline $\begin{array}{lr}\text { Solusi } & \text { Menang } \\
\text { Bersama } & \text { (Win-win } \\
\text { Solution) } & \end{array}$ & $\begin{array}{l}\text { Pendekatan ini menekankan pada pihak yang bernegosiasi } \\
\text { mempunyai niat untuk bersama-sama dimenangkan tanpa } \\
\text { melakukan penekanan atau desakan yang berlebihan kepada } \\
\text { pihak-pihak yang sedang melakukan negosiasi }\end{array}$ \\
\hline $\begin{array}{lr}\text { Strategi } & \text { Menang- } \\
\text { kalah } & \text { (Win-Lose } \\
\text { Strategy) } & \end{array}$ & $\begin{array}{l}\text { Pendekatan dengan menggunakan strategi menang kalah } \\
\text { merupakan negosiasi yang berfokus pada kemenangan di } \\
\text { satu pihak dan kekalahan dipihak yang lain. Startegi menang } \\
\text { kalah dapat menimbulkan konflik yang berkepanjangan karena } \\
\text { hanya satu pihak yang memperoleh kemenangan sementara } \\
\text { pihak yang lain mengalami kekalahan. }\end{array}$ \\
\hline $\begin{array}{l}\text { Strategi Kalah-Kalah } \\
\text { (Lose-lose Strategy) }\end{array}$ & $\begin{array}{l}\text { Strategi dengan menggunakan pendekatan kalah-kalah } \\
\text { seringkali dilandasi oleh perasaan untuk melampiaskan } \\
\text { kemarahan atau kebencian sehingga proses negosiasi } \\
\text { cenderung tidak rasional. Kedua belah pihak memutuskan } \\
\text { untuk kalah dan sama-sama mengakhiri proses negosiasi } \\
\text { dengan hasil tidak menghasilkan kesepakatan. }\end{array}$ \\
\hline
\end{tabular}


Agar proses negosiasi dapat berjalan dengan lancar dan optimal, diperlukan tahapan-tahapan komunikasi yang sangat berperan penting. Dalam gambar dibawah disajikan tahapan yang menjadi segment penting dalam proses negosiasi.

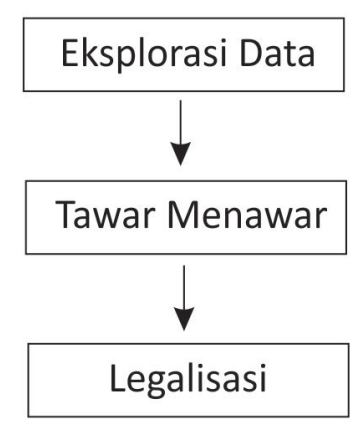

Gambar 1

Tahapan Negosiasi

Tahapan komunikasi dalam proses negosiasi dapat dirincin sebagai berikut :

1. Eksplorasi atau penggalian data

Eksplorasi dilakukan dengan cara mengidentifikasi dan menganalisa masalah secara terperinci, kemudian dianalisa sehingga didapatkan kesimpulan beserta solusinya.

2. Tawar Menawar

Tawar menawar dilakukan dengan cara melakukan diskusi dan perundingan untuk mencapai kesepakatan antara perusahaan dengan pelanggan. Dalam proses ini perusahaan maupun pelanggan dapat menyampaikan ide-idenya sehingga kesepakatan dapat di capai.

3. Legalisasi

Merupakan pengesahan hasil kesepakatan negosiasi antara perusahaan dengan pelanggan yang dicantumkan secara tertulis dalam sebuah dokumen kesepakatan yang dapat berupa terbitnya surat pesanan atau terjadinya perjanjian yang sering disebut dengan MoU (Memorandum of Understanding).

2. Lobi

Kegiatan lobi merupakan aktivitas komunikasi yang sering dilakukan oleh perusahaan distribusi dengan pelanggan. Lobi merupakan tindakan informal yang sitematis yang dilakukan oleh perusahaan distribusi dalam rangka menciptakan hubungan dalam jangka panjang dan saling menguntungkan dengan pelanggannya. Aktivitas ini sering dilakukan oleh tim penjualan, tetapi dalam skala yang lebih besar biasanya ditangani oleh Branch Manager.

Lobi merupakan suatu upaya pendekatan informal dan persuasive yang dilakukan 
oleh satu pihak yang memiliki kepentingan tertentu untuk menarik dukungan dari pihak-pihak yang dianggap memiliki pengaruh atau wewenang, sehingga target yang diinginkan tercapai. (Anwar, 1997:76). Pendekatan secara persuasive dalam hal ini lebih disampaikan oleh pihak pelobi, sehingga dibutuhkan keaktifan pelobi untuk menunjang kegiatan ini.

Dalam prakteknya lobi memiliki sejumlah fungsi yang sangat penting bagi perusahaan. Adapun fungsi lobi diantaranya :

a. Mempengaruhi perusahaan dan pelanggan agar keputusan yang diambil tidak merugikan kedua belah pihak.

b. Memprediksi berbagai kemungkinan yang dapat terjadi ketika sebuah kebijakan dan keputusan diambil, baik oleh perusahaan maupun pelanggan.

c. Sebagai sumber informasi tentang kondisi yang dapat terjadi ketika sebuah kebijakan diambil oleh perusahaan atau pelanggan.

d. Memberi keyakinan kepada perusahaan atau pelanggan, bahwa pelaksanaan suatu kebijakan membutuhkan waktu dan momentum yang tepat.

Dalam aktivitas lobi antara perusahaan distribusi dengan pelanggan biasanya berkaitan dengan proses penjualan. proses pengiriman, proses pembayaran yang memang seringkali kebijakannya dapat berubah, sehingga membutuhkan suatu pendekatan yang sifatnya relationshif.

3. Presentasi Bisnis

Dalam kegiatan komunikasi dengan pelanggan, presentasi bisnis dengan pelanggan merupakan salah satu faktoryang dapat menunjang keberhasilan sebuah perusahaan distribusi. Presentasi kepada pelanggan dilakukan untuk memberikan informasi kepada pelanggan mengenai data penjualan pelanggan, aktual program promosi yang sedang berjalan, serta permasalahan lain yang berkaitan dengan pelanggan sehingga menghasilkan transaksi kepada perusahaan dan dapat membangun hubungan jangka panjang dengan pelanggan.

Secara umum kegiatan presentasi bisnis ditujukan untuk membangun komunikasi dengan pelanggan yang berkaitan dengan aktivitas bisnis yang sudah dilakukan. Adapun tujuan dari presentasi bisnis adalah :

a. Memberikan informasi

Memberikan informasi merupakan upaya komunikasi yang dilakukan perusahaan dalam kegiatan presentasi bisnis. Presentasi mempunyai tujuan memberikan informasi atau menganalisis situasi antara pembicara dengan pelanggan. Setelah presentasi selesai maka akan terjadi proses diskusi, tanya jawab sehingga diharapkan pelanggan dapat memberikan umpan balik, yang akhirnya dapat menghasilkan perubahan sikap, pendapat, serta partisipasi aktif 
dari pelanggan.

b. Mempengaruhi pelanggan

Dalam proses mempengaruhi pelanggan antara presentator dan pelanggan dengan sengaja saling berkomunikasi untuk saling mempengaruhi. hal yang sering dilakukan untuk saling mempengaruhi, diantaranya adalah gambaran mengenai fakta-fakta yang dapat meningkatkan pemahaman pelanggan tentang isu-isu pasar yang sedang berkembang, argumentasi dengan bujukan persuadif agar pelanggan yakin dengan isu yang disampaikan dan yang terakhir adalah menyampaikan kesimpulan atau rekomendasi tertentu sehingga pelanggan mengambil keputusan sesuai yang perusahaan harapkan setelah pelanggan menerima argumentasi yang disampaikan kepada mereka

\subsection{Perusahaan Distribusi dengan Pelanggan}

Dalam operasional perusahaannya, tugas perusahaan distribusi adalah mendistribusikan produk dari principal sampai ke pelanggan yang menjadi target distribusi, yaitu Traditional Market yang merupakan pelanggan-pelanggan yang biasanya berbentuk tradisional dan di kelola sendiri, Modern market yang merupakan pelangggan yang sudah mempunyai manajemen tersendiri serta Whole Seller yang merupakan pelanggan dengan pembelian sangat besar.

Perusahaan distribusi mempunyai peranan yang sangat penting dalam proses penyediaan barang, fungsi distribusi adalah sebagai pengubung agar produk yang telah diproduksi dapat sampai ke pelanggan sesuai dengan kebutuhan pelanggan tersebut. Dalam pengertiannya Perusahaan distribusi merupakan suatu badan organisasi yang dapat menyediakan barang dan memiliki rekanan rekanan untuk menjual barangnya kembali dengan harga yang tinggi untuk

Pembagian tugas dan tanggung jawab susunan organisasi yang ada didalam perusahaan distribusi yaitu :

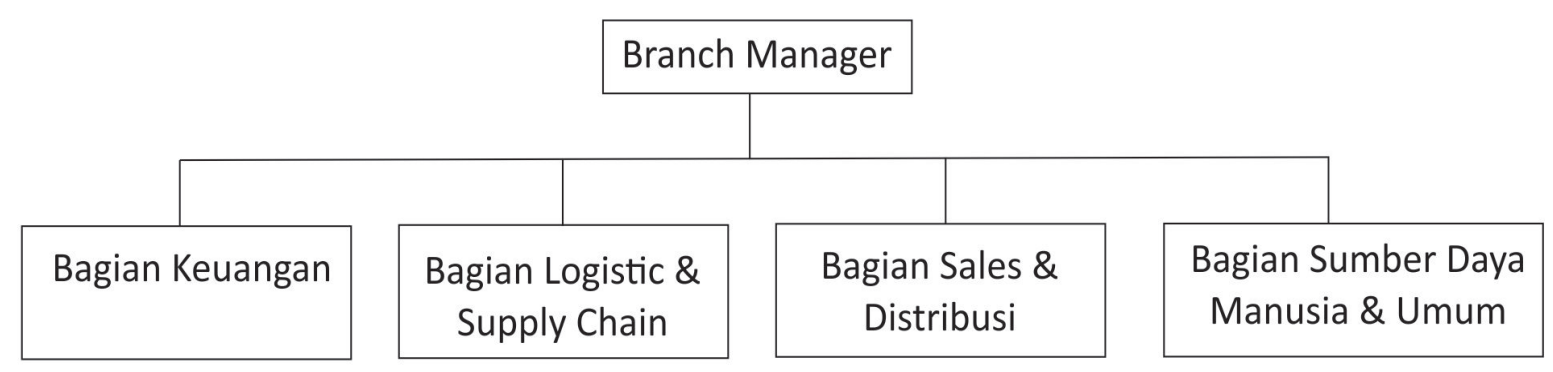

\section{Gambar 2}

Struktur Organisasi Perusahaan Distribusi 
1. Kepala Cabang/Branch Manager

- Mengkoordinir seluruh sub koordinasi dalam menjalankan fungsinya masingmasing.

- Merumuskan kebijakan dan pedoman strategi perusahaan secara menyeluruh.

- Mewakili perusahaan secara legal formal dalam menjalin hubungan dengan pihakpihak eksternal .

- Menjalankan fungsi pengawasa perusahaan.

- Memberikan bimbingan kepada seluruh karyawan perusahaan.

2. Bagian Akuntansi dan keuangan

- Menyusun, melaksanakan dan mengendalikan pelaksanaan sistem akuntansi manajemen, sistem akuntansi keuangan, perpajakan dan tehnologi informasi agar dapat mendukung kebijakan perusahaan.

- Menyusun, melaksanakan dan mengendalikan pengelolaan keuangan perusahaan sehingga tercipta optimalisasi keuangan serta pembiayaan secara komprehensif.

3. Bagian Logistik dan Suply chain

- Melakukan perencanaan, pelaksanaan dan pengendalian kebijakan perusahaan dibidang logistik dan supply chain serta manajemen resiko.

- Menjalankan strategi, kebijakan serta operasional persediaan barang yang akan didistribusikan.

4. Bagian Sales dan Distribusi

- Membantu kepala cabang dalam perencanaan, pengendalian kebijakan strategis perusahaan dalam bidang distribusi.

- Menjalankan strategi, kebijakan, serta pelaksanaan distribusi dan penjualan seluruh produk.

- Mengevaluasi penjualan, distribusi dan melakukan perbaikan terhadap team penjualan sehingga tercapai target yang diberikan.

5. Bagian Sumber Daya Manusia dan Umum

- Menyusun, melaksanakan, dan mampu mendukung pelaksanaan kebijakan perusahaan yang berkaitan dengan permasalahan Sumber Daya Manusia agar mampu memenuhi pengembangan organisasi dan bisnis.

- Mendukung pelaksanaan kebijakan perusahaan yang berkaitan dengan hukum dan komunikasi korporasi.

Bagi perusahaan distribusi komunikasi mempunyai peranan yang penting bagi pelanggan. Proses komunikasi yang dilakukan perusahaan kepada pelanggan dapat berupa proses penyampaian pikiran, informasi, peraturan, atau instruksi dari perusahaan terhadap suatu cara tertentu agar pelanggan memahami pesan yang diterimanya secara efektif, untuk itulah mempunyai manfaat yang penting kepada pelanggan. Adapu pentingnya komuniukasi 
kepada pelanggan adalah :

a. Pelanggan berhak mengetahui tentang makna penting produk perusahaan bagi mereka.

b. Pelanggan berhak mengetahui bahwa perusahaan menyediakan layanan informasi sesuai yang mereka inginkan dalam rangka memenuhi kebutuhan dan keinginan pelanggan.

c. Pelanggan berhak tahu bahwa perusahaan dapat membantu pelanggan agar segala sesuaitu yang berkaitan dengan kebutuhannya dapat terpenuhi.

d. Pelanggan berhak tahu bahwa perusahaan menyediakan sarana dan prasarana yang memadai sehingga ketika terjadi keluhan yang mereka rasakanb dapat segera disampaikan ke perusahaan.

e. Pelanggan berhak mendapatkan pelayanan yang terbaik dengan waktu dan usaha seminimal mungkin. (Somad dan Priansa, 2014:30).

\section{Metode Penelitian}

Jenis penelitian yang digunakan untuk melakukan penelitian ini adalah jenis penelitian kualitatif, dimana pada hakekatnya adalah mengamati fenomena orang, peristiwa, proses, gejala dalam lingkungan hidupnya, berinteraksi dengan mereka dan berusaha memahami mengenai dunia mereka. Metode penelitian yang digunakan yaitu metode deskriptif analisis yang merupakan suatu metode yang menggambarkan dan memaparkan suatu peristiwa pada waktu peneliti mengadakan penelitian. Informan ditentukan melalui tehnik penentuan informan yang purposive, yaitu informan yang memiliki kharakteristik tertentu yang relevan dengan penelitian ini. Subyek yang dipilih secara purposive karena yang digali dalam penelitian ini adalah kedalaman informasi bukan kuantitas, yaitu Branch Manager, Bagian sales, keuangan dan supply chain di perusahaan distribusi.

\section{Hasil Penelitian dan Pembahasan}

Komunikasi dalam perusahaan terbentuk karena masing-masing unsur yang tergabung dalam perusahaan harus mampu berkomunikasi dengan pelanggan. Adapun unsur-unsur komunikasi yang harus dibangun dalam perusahaan sama dengan unsur dalam berkomunikasi. Adapun unsur-unsur komunikasi kepada pelanggan tersebut adalah :

a. Komunikator

Komunikator dalam hal ini adalah karyawan dalam perusahaan yang akan menyampaikan pesan kepada pelanggan.

b. Komunikan

Komunikan adalah pelaku yang menerima pesan, yang dimahsud dalam hal ini adalah pelanggan. Komunikan dapat bertindak sebagai komunikan individu maupun 
komunikan kelompok, dapat juga dalam bentuk perorangan maupun korporasi.

c. Pesan

Pesan berupa inti atau berita yang mengandung arti, oleh karena itu pesan yang disampaikan organisasi bisnis harus dirancang sedemikian rupa sehingga pesan tersebut dapat menarik perhatian pelanggan. Organisasi bisnis perlu memilih dan merancang pesan menarik sehingga akan mendapat respon yang baik dari pelanggan.

d. Umpan Balik

Umpan balik adalah keluaran yang dihasilkan, yang dapat berupa tanggapan atau respon dari pesan (message) yang disampaikan oleh organisasi bisnis bisnis kepada pelanggan. Umpan balik dalam komunikasi antara lain adalah:

- Umpan Balik Kosong Umpan yang diterima organisasi bisnis dari pelanggan tidak dapat dimengerti, sehingga tujuan yang ingin disampaikan oleh pelanggan tidak dapat dipahami dengan baik.

- Umpan Balik Positif Umpan balik positif artinya bahwa pesan yang disampaikan oleh organisasi bisnis kepada pelanggan dapat dimengerti dengan baik.

- Umpan Balik Netral

Umpan balik netral artinya umpan balik tidak memihak. Artinya pesan yang dikembalikan oleh pelanggan kepada organisasi bisnis tidaklah relevan atau tidak ada hubungannya dengan masalah yang disampaikan oleh organisasi bisnis kepada pelanggan.

- Umpan Balik Negatif

Umpan balik negative adalah artinya pesan yang dikembalikan oleh pelanggan kepada organisasi bisnis tidaklah mendukung atau menentang, yang artinya terjadi kritikan atau kemarahan dari pelanggan kepada organisasi bisnis.

e. Transmit

Transmit artinya menyampaikan, mengirimkan, atau menyebarkan pesan. Dalam pengiriman pesan bisa dilaksanakan secara langsung atau pun secara tidak langsung. Pengiriman pesan secara langsung pada dasarnya akan lebih efektif hasilnya dibanding dengan pengiriman pesan secara tidak langsung, karena penyampaian pesan secara tidak langsung organisasi bisnis membutuhkan media atau sarana yang khusus untuk melakukan penyampaian pesan tersebut.

f. Media Komunikasi

Pemilihan media komunikasi membutuhkan keterampilan dan kejelian dari organisasi bisnis. Media komunikasi yang dipilih dapat berwujud media tertulis, lisan, dan lain sebagainya, ataupun kombinasi dari keseluruhan media sesuai dengan tujuan dan 
kepentingan dalam pesannya kepada pelanggan. Organisasi bisnis perlu memiliki kemampuan memilih media komunikasi yang tepat.

g. Gangguan

Gangguan atau barrier dalam berkomunikasi dapat terjadi pada setiap unsure komunikasi. Gangguan harus dihilangkan atau diminimalisir agar komunikasi yang terjadi antara organisasi bisnis dan pelanggan menjadi lebih efektif.

Dalam pola komunikasi di perusahaan distribusi semua sub bagian dalam struktur organisasi akan selalu melakukan hubungan timbal balik. Satu bagian tidak dapat bekerja sendiri karena setiap proses pekerjaan pasti membutuhkan kerja sama antar bagian agar sebuah proses pemesanan dari pelanggan dapat terkirim baik ke konsumen. Semua proses yang dilakukan harus mendapatkan persetujuan dari Branch Manager, untuk itulah peran Branch manager di perusahaan distribusi sangat besar dan menentukan. Adapun pola komunikasi yang ada didalam perusahaan distribusi adalah :

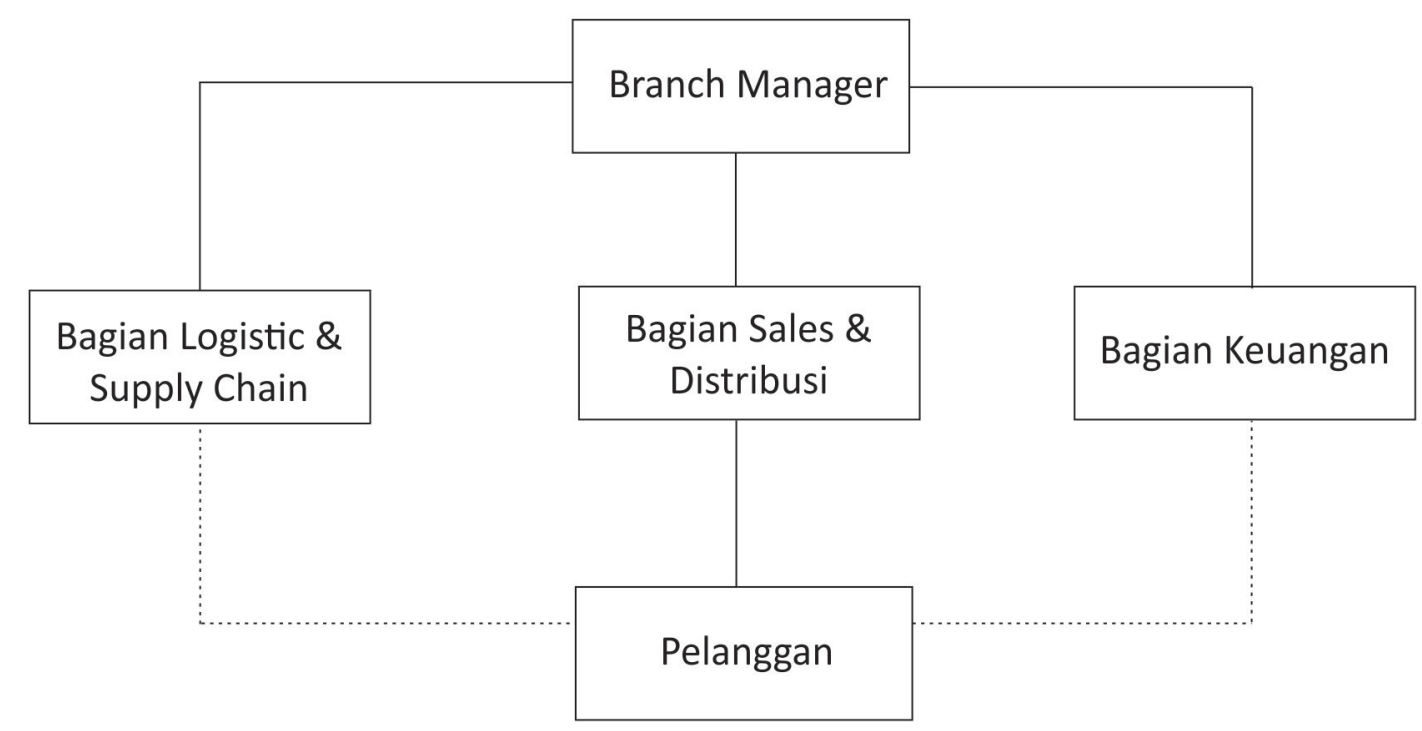

\section{Gambar 3}

Pola Komunikasi Perusahaan Distribusi

Pola komunikasi diartikan sebagai bentuk atau pola hubungan dua orang atau lebih dalam proses pengiriman dan penerimaan pesan yang melibatkan dua komponen yaitu gambaran atau rencana yang meliputi langkah-langkah yang akan dilakukan dalam suatu aktifitas perusahaan, yang merupakan komponen-komponen penting dalam hubungan komunikasi antara perusahaan dengan pelanggan.

Setiap bagian dari struktur organisasi yang berada di perusahaan mempunyai peran masing-masing sehingga produk sampai di tangan pelanggan. Pola komunikasi dalam layanan 
produk yang di pesan ke perusahaan distribusi membutuhkan tahapan-tahapan komunikasi agar produk sampai ke pelanggan. Tahapan tersebut adalah :

1. Komunikasi bagian sales dan distribusi

Komunikasi yang dilakukan oleh bagian sales dan distribusi lebih banyak menggunakan komunikasi langsung dan bersifat tatap muka. Komunikasi yang dilakukan bertujuan untuk membina hubungan, mencari kebutuhan, menyesuaikan produk yang sesuai dengan kebutuhan pelanggan, serta mengkomunikasikan manfaat dari produk dengan cara menginformasikan, mengingat atau membujuk pelanggan sehingga mereka bersedia melakukan transaksi. Semua komunikasi tersebut dilakukan dalam rangka menghasilkan penjualan bagi perusahaan.

Adapun cara yang dilakukan oleh bagian sales dan distribusi adalah :

a. Menyebar luaskan informasi kepada pelanggan.

Bagian sales dan distribusi berperan penting didalam menyampaikan informasi produk perusahaan kepada pelanggan, misalnya informasi terkait dengan produk, harga yang telah disepakati, discount yang ditetapkan, waktu pengiriman, sistem pembayaran, servise purna jual dan lainnya.

b. Membujuk atau mempengaruhi pelanggan

Bagian sales dan distribusi berperan dalam membujuk dan mempengaruhi pelanggan untuk dapat terjadinya sebuah transaksi penjualan. Contohnya adalah dengan memperagakan produk serta memberikan edukasi dan pengaruh agar pelanggan merasa bahwa mereka membutuhkan produk tersebut dan sesuai dengan keinginannya.

c. Memberikan pelayanan kepada pelanggan

Bagian sales dan distribusi berusaha membantu pelanggan, agar pelanggan menyadari kebutuhan atau keinginannya tentang produk perusahaan, misalnya dengan cara menyampaikan berbagai hal yang berkaitan dengan produk yang dibelinya, termasuk juga informasi mengenai pasca jual seperti garansi produk, atau pengembalian barang ketika rusak atau expire date.

d. Memberikan informasi pasar kepada pelanggan dan perusahaan

Bagian sales dan distribusi sangat berperan dalam memberikan informasi mengenai situasi pasar yang terjadi kepada pelanggan dan perusahaan. Dalam informasi pasar kepada pelanggan lebih bagaimana informasi kesediaaan stok, informasi harga, sementara dalam sisi perusahaan dapat berupa informasi mengenai perubahan harga competitor, program kompetitor dan sebagainya.

2. Komunikasi Bagian Logistik dan supply chain

Meskipun lebih banyak tidak terlibat secara langsung dengan pelanggan, bagian logistic dan supply chain mempunyai peran yang penting dalam proses distribusi 
produk kepada pelanggan. Bagian ini bekerja sama dengan bagian sales dan distribusi akan menyampaikan informasi kepada pelanggan mengenai ketersediaan stok yang ada. Komunikasi langsung yang dimungkinkan biasanya terjadi pada waktu pengiriman produk kepada pelanggan, baik mengenai durasi waktu pengiriman ataupun estimasi produk akan sampai kepada pelanggan.

3. Komunikasi Bagian Keuangan

Komunikasi bagian Keuangan menitik beratkan pada sistem pembayaran dari pelanggan kepada perusahaan. Meskipun tidak secara langsung ke konsumen, bagian keuangan harus dapat mengkomunikasikan kepada pelanggan mengenai model pembayaran yang berlaku dalam perusahaan apakah pembayaran langsung menggunakan tunai, menggunakan Bilyet Giro atau dengan sistem transfer. Hal yang sering terjadi juga adalah bagaimana berkomunikasi kepada pelanggan ketika terjadi Block order karena permasalahan Top of Payment (TOP).

4. Komunikasi Branch Manager

Peran komunikasi Branch manager sangat penting baik di internal perusahaan maupun kepada pelanggan. Dalam komunikasi internal Branch manager harus mampu menjembatani permasalahan yang terjadi dalam internal perusahaan yang berkaitan dengan pelanggan. Dalam komunikasi dengan pelanggan Branch Manager harus mampu membangun komunikasi ketika terjadi ketidakkesepakatan penjualan antara perusahaan dengan pelanggan serta melakukan relationship yang baik sehingga terjadi proses hubungan yang baik jangka panjang dengan pelanggan

Peta persaingan bisnis yang semakin meningkat termasuk juga perubahan perilaku pelanggan, serta perubahan teknologi dalam proses penjualan ke pada pelanggan mendorong perusahaan distribusi untuk lebih fokus dalam membangun hubungan komunikasi yang baik pelanggan. Dalam jangka panjang, menjaga pelanggan menjadi tujuan bagi perencanaan strategic, hal ini dikarenakan hubungan positif antara perusahaan dengan pelanggan merupakan driver bagi kesinambungan perusahaan.

Beberapa strategi komunikasi yang dilakukan bagi perusahaan distribusi dalam menjaga pelanggan mereka agar tetap menjadi pelanggan yang mempunyai hubungan yang positif dengan perusahaan, yaitu :

1. Mendengarkan keluhan pelanggan

keluhan pelanggan sangat perlu didengarkan oleh perusahaan melalui tanggapan dan layanan yang cepat. Keluhan pelanggan biasanya berkaitan dengan perasaan tidak puas pelanggan terhadap layanan yang diberikan perusahaan. Perusahaan perlu memberikan perhatian serta tanggapan yang baik dan cepat atas keluhan pelanggan tersebut sehingga pelanggan merasa mendapatkan penanganan atas permasalahannya. Respon cepat dan baik dalam menangani keluhan pelanggan 
akan merasa senang dan memeperkecil pindah dengan competitor.

2. Mengunjungi pelanggan

Mengunjungi pelanggan merupakan sebuah langkah yang penting bagi bisnis perusahaan. Kunjungan pelanggan di perusahaan distribusi biasanya dilakukan oleh team sales perusahaan berdasarkan rute dan waktu kunjungan. Akan tetapi ada kalanya pelanggan akan merasa lebih terhoirmat ketika suatu saat dikunjungi oleh Branch Managernya sehingga tercipta hubungan yang baik, harmonis dan adanya keterikatan antara perusahaan dengan pelanggan.

3. Menjaga sikap kepada pelanggan

Perusahaan perlu mengetahui bagaimana sikap dan layanan karyawan perusahaan dalam memberikan layanan kepada pelanggan. Salah satu cara yang dilakukan adalah ketika kunjungan Branch Manager ke pelanggan dapat ditanyakan bagaimana sikap karyawan perusahaan daam memberikan layanan kepada pelayanan pelanggan, baik dari proses pra penjualan, penjualan, layanan kiriman barang maupun pasca penjualan. Salah satu tujuan dari kegiatan ini adalah untuk menetapkan standar sikap atau standar operasional layanan kepada pelanggan.

4. Melayani sesuai dengan karakter pelanggan

Perusahaan melalui karyawannya harus mampu memberikan layanan kepada pelanggan sesuai dengan karakter mereka. Banyak ditemui beberapa model karakter pelanggan yang terbuka, rewel, sangat sensitive dan sebagainya. hal ini membutuhkan penanganan yang berbeda-beda sehingga peruahaan perlu menggunakan pendekatan yang paling tepat terutama dalam menangani keluhan pelanggan atas layanan yang diberikan perusahaan.

5. Ketidakpuasan pelanggan merupakan informasi berharga bagi perusahaan Banyak pelangggan yang tiba-tiba berpindah dengan competitor lain. Hal ini disebabkan tidak semua pelanggan akan mengeluhkan langsung ketidakpuasan mereka kepada perusahaan. Untuk itu sangat perlu bagi perusahaan untuk melakukan riset untuk mengetahui sisi kepuasan pelanggan maupun sisi ketidakpuasan pelanggan. hasil riset dapat dapat digunakan sebagai feed back bagi perusahaan untuk melakukan perbaikan sisi layanan yang berkelanjutan.

\section{SImpulan}

Dalam perusahaan distribusi pelanggan merupakan objek vital bagi perusahaan. Perusahaan dapat bertahan hidup, mendapatkan laba optimal dan mengalami pertumbuhan bisnis yang tinggi dalam persaingan competitor yang sangat ketat jika mampu mengidentifikasi dan menjaga kebutuhan serta keinginan pelanggan dengan baik. Keberhasilan bisnis perusahaan tidak hanya ditentukan oleh produk atau jasa yang dijual, tetapi diperlukan strategi komunikasi 
yang berorientasi dengan pelanggan, dimana tercipta komunikasi antara perusahaan dengan pelanggan yang berkesinambungan yang merupakan salah satu kunci utama bagi perusahaan dalam menyampaikan informasi yang berkaitan dengan mengumpulkan kebutuhan dan keinginan pelanggan yang harus dipenuhi oleh perusahaan, sekaligus memberikan nilai (value) yang lebih baik dibandingkan oleh competitor.

\section{Daftar Pustaka}

Bovee L Courtland, Thill V John. (2008). Business Communications Today 9 Edition. Pearson Prentice hall

Curtis Dan, Floyd James, Winsor L Jerry. (2006). Business and Profesional Communication. Harper Collins Publisher Inc

GFarber, Barry. (2003). Superstar Wiraniaga Secrets. Career Press.

Hasan, Ali. (2013). Marketing. Yogjakarta. CAPS

Kotler, Philip. (2002). Manajemen Pemasaran, Edisi Millenium. Jakarta: Prenhallindo.

Kurniawan, Arief Rakhman. (2014). Total Marketing. Yogyakarta: KOBIS

Lupiyoadi. (2001). Manajemen Pemasaran Jasa Teori dan Praktek. Jakarta: Salemba Ampat

Manning,G.L \& Barry L.Reece. (2006). Selling Today. Jakarta: PT. Indeks

Marwanto, Aris. (2015). Marketing Sukses. Yogyakarta: KOBIS

M. Nasution. (2005). Total Quality Management. Jakarta: PT. Gramedia Pustaka Utama

Rivai, Veitzal, Mohd Basri \& Ahmad fawzi. (2005). Performance Appraisal: System yang tepat untuk menilai kerja karyawan dan meningkatkan daya saing perusahaan. Jakarta: PT. Raja Gravindoi Persada.

Robbins, Stephen P. (2009). Perilaku Organisasi. Jakarta:Salemba Empat.

Stewart, Grant. (2000). Succesful Sales Management. Pearson Education Limited.

Somad, Rismi \& Priansa Donni Juni. (2014). Manajemen Komunikasi. Bandung: Alfabeta.

Suharsono, Dewantara, Lukas. (2013). Komunikasi Bisnis. Yogyakarta: CAPS 